\title{
PREPAID TICKETS TO THE NEW WORLD: THE NEW YORK CONTINENTAL CONFERENCE AND TRANSATLANTIC STEERAGE FARES 1885-1895*
}

TORSTEN FEYS

European University Institute ${ }^{a}$

\begin{abstract}
RESUMEN
Este artículo examina la situación de los cárteles del transporte naviero (conferencias) que regularon el transporte migratorio transatlántico del continente europeo a los Estados Unidos. El objetivo del artículo es identificar las presiones internas y externas subyacentes a estos acuerdos, así como las estrategias empleadas para neutralizar estas presiones. El autor llega a la conclusión de que un acuerdo sobre la división del mercado en quatos (market shares) era esencial para la eficacia de la Conferencia, que era al mismo tiempo una forma de integración horizontal que regulaban la competencia entre las compañías de transporte naviero, así como una integración vertical para obtener el control sobre la red de agentes transatlánticos de venta de billetes a la emigración. El autor correlaciona también la eficacia de los acuerdos con las tarifas para emigrantes y los costes de la migración.
\end{abstract}

Palabras clave: cárteles de transporte naviero, migración, tarifas para emigrantes, redes marítimas siglo XIX

* Received 12/11/2006. Accepted 04/25/2008. This article is part of an ongoing PhD research at the European University Institute, Florence (Italy) entitled: «The Battle for the migrants: The introduction of steam-shipping on the North Atlantic and its impact on the European Exodus 1840-1914».

a Torsten.Feys@eui.eu. 


\begin{abstract}
This article surveys the situation of the shipping cartels (conferences) which regulated transatlantic migrant transport from the European Continent to the United States. The focus of the article is to identify the internal and external pressures underlying these agreements and the strategies employed to neutralize these pressures. The author reaches the conclusion that a pool agreement was essential for the effectiveness of the Conference, which was both a means of horizontal integration regulating the competition between shipping companies and a means of vertical integration to gain control over the transatlantic migrant agent network selling the ocean passage tickets. The author also correlates the efficiency of the agreements with steerage fares and migration costs.
\end{abstract}

Keywords: shipping cartels, migration, steerage fares, maritime networks $19^{\text {th }}$ century

JEL Classification: D4, N80, F22, N80

\title{
INTRODUCTION
}

Shipping conferences or rings are collusive agreements to mitigate competition and reduce the effects of trade fluctuations, primarily to regulate prices and market shares ${ }^{1}$. Their origins are generally ascribed to the need of shipping companies to ease the pressures of destructive competition which cut prices and profits as a result of overcapacity on certain routes ${ }^{2}$. It is generally agreed that the first shipping conference was the UK-Calcutta Conference regulating the tea trade established in $1875^{3}$. Yet there are clear indications that similar agreements were concluded much earlier in the North Atlantic ${ }^{4}$. The practice spread quickly and is still in use today; more than 150 conferences were operative in $2001^{5}$. Research on shipping rings

\footnotetext{
1 Ville (1990, p. 95).

2 Greenhill (1998, pp. 58-59).

3 Deakin and Seward (1973, pp. 1-3), Ville (1990, p. 95)

4 Sloan uncovered secret agreements between Cunard and Collins, fixing minimum rates and pooling revenues for both passengers and cargo during the 1850 s. Hyde found indirect evidence that by 1868 a conference agreement, fixing freight rates and minimum passenger fares was reached between the Glasgow and Liverpool steamshipping companies. Hvidt found evidence that, as early as 1871, migrant brokers in Copenhagen organized themselves in a sub-conference regulating local business and reporting to the main body in Liverpool. See Aldcroft (1974, p. 289), Hvidt (1978, p. 193), Hyde (1975, p. 94), Sloan (1992 and 1998).

5 Sjostrom (2004, p. 82).
} 
has concentrated on freight transport, yet these did not manage to reverse the tide of sharply decreasing freight rates throughout the nineteenth century $^{6}$. As Jeffrey Williamson and Timothy Hatton underlined, this decline was the main factor behind the convergence of the commodity market before 1914. At the same time, they highlighted the importance of migration in the development of the Atlantic economy ${ }^{7}$. We know little, however, about the price formation of transatlantic passenger fares. Drew Keeling and Knick Harley's reconstructions of yearly averages for the Cunard Line show that, unlike freight rates, passenger fares increased ${ }^{8}$.

This article sheds more light on why passenger fares rose by analyzing the formation of third class migrant rates through conference agreements between four Continental lines; Holland America Line (HAL) Red Star Line (RSL), North German Lloyd (NGL) and Hamburg America Line (HAPAG) for the period 1885-1895. So far, Erik Murken's research on the pool agreement between these lines, the "Nord-Atlantischer Dampfer-Linien Verband» (NDLV), established in 1892, remains the only substantial research of shipping rings regulating passenger trade. Subsequently, the NDLV made arrangements with other companies and conferences which, by 1914, had become a horizontal alliance including twelve separate agreements between 30 lines carrying passengers on the North Atlantic route ${ }^{9}$. This article analyzes the growing pains of the conference system which preceded the pool agreements and its impact on transatlantic migrant fares, applying Osborne's cartel formation model and reconstructing the external and internal pressures on the agreements. As also underlined by Stigler, the key to the success of a cartel depended on the ability of its members to detect and deter cheating on the agreements. This was also the main obstacle faced by the continental lines in the search for a workable equilibrium ${ }^{10}$. Since these passenger agreements were complex, meaning that firms colluded on variables other than price, such as delimitating the members' territory or coordinating sailing schedules, the incentives to cheat were stronger than a simple price agreement and hence the importance of finding efficient means to monitor the conference increased ${ }^{11}$. In the case of passenger conferences many clauses dealt with the coordination of the wide network of migrant agents or brokers and the regulation of their sales of ocean passage tickets. As will be argued for the American market of ocean passage sales, the lack of control over this network made any price agreements void.

The research is based on the minutes of the Continental Conference in New York and on the correspondence between the head-agent in New York,

6 Deltas, Sicotte and Serfes (1999, p. 3), Harley (1971, pp. 228-229 and 1988, pp. 851-876), North (1958, pp. 538-555).

7 Williamson and Hatton (1994, pp. 7-16 and 1998).

Harley (1990, pp. 147-172), Keeling (1999a, pp. 64-65).

Murken (1922).

10 Osborne (1976, pp. 835-844), Stigler (1964, pp. 44-61).

11 Deltas, Sicotte and Serfes (1999, pp. 2-10). 
W. H. Van den Toorn, and the board of directors of the HAL. It reveals how the company organized the booming markets of eastbound tickets for return or repeat migrants, reaching 30 per cent of the westbound movement by the turn of the century and prepaid tickets sold in the US for passengers to make the crossing from Europe, which for the HAL represented 50 per cent of its westbound business ${ }^{12}$. The minutes give further detail on ways in which the conference tried to neutralize internal and external competition and contains the dates when members adapted their third class fares. The correspondence between the head-agent and the board of directors, which gives an inside view of the organization of passenger business, is even more revealing. Since most of the decisions of the New York Continental Conference required the approval of the directors and depended on parallel conference agreements regulating the European cash business, an intense correspondence was generated. Like the work of Genesove and Mullin on the sugar cartel, the correspondence provides insights into the reasoning behind the firm's actions and what was significant during the negotiations to reach an agreement ${ }^{13}$.

\section{THE HOLLAND AMERICA LINE AND THE ORGANIZATION OF OCEAN PASSAGE SALES}

Gordon Boyce underlined the co-operative dimension of shipping conferences, its importance in shaping relations between shipping companies and between shippers and shipowners and criticized economists for focusing on market power and the cost/service driven necessity of conference regulation ${ }^{14}$. The main difference between the shipment of cargo and that of migrants is that the former is supplied by shippers in the port while the latter is provided by a wide network of migrant brokers, agents and subagents spread on both sides of the Atlantic. Models explaining the viability of conferences are based upon a common interest between shippers and ship owners ${ }^{15}$. Conversely, between ship-owners and the various layers of middlemen; migrant brokers, agents and sub-agents, this common interest hardly existed. These go-betweens worked on a commission basis for different lines. Commissions increased when competition among shipping companies intensified and therefore agents had few reasons to favor a stable market. To increase their profits, shipping companies needed to find ways to tighten their grip on the agents.

The HAL offers a representative example of how passenger lines organized their sales. Founded during the steamship boom of the early 1870 s when

\footnotetext{
12 Bastin (1971, pp. 63-65), Murken (1922, p. 47).

13 Genesove and Mullin (2001, pp. 379-398).

14 Boyce (1995, p. 161).

15 Pirrong (1992, pp. 89-131), Sjostrom (2004, pp. 88-95).
} 
the transition from sail to steam on the North Atlantic passenger market took place, the HAL appointed migrant brokers who managed the passage business for the company on both sides of the Atlantic; Van Es, Wambersie \& Ruys in Rotterdam for the "European cash business» and Morris \& Co in New York for the "eastbound and prepaid markets». As early as 1877 the HAL decided to change this situation and took the European passenger business into its own hands becoming responsible for a vast agent-network which rapidly numbered more than two thousand members ${ }^{16}$. In New York, Morris \& Co supervised a nationwide network totaling one thousand four hundred members. Most agents also had another main job and some were innkeepers, priests, hotel-owners, notaries, insurers, bankers, mine-owners, railroad employees, newspaper-editors, storekeepers, etc. In the US, migrant entrepreneurs usually combined several such occupations, yet banking and the sale of ocean passage tickets were essential features of their business. Sharing ethnic ties with migrants allowed these entrepreneurs to gain the trust of new arrivals who often relied on them for housing, jobs and legal documents, but above all to assist them with their savings which became the primary goal of the move as transatlantic migration became less permanent with the introduction of steam. Migrants used short term target accumulation as part of their migration strategy; saving towards a remittance or steamship tickets to go back home or have family and friends join them ${ }^{17}$. The sale of ocean passages allowed migrant entrepreneurs to earn a commission, but above all it made it possible for them to contact potential laborers or clients for other businesses. Steamship companies provided them with rate and time table sheets, advertising materials and ticket books but generally failed to generate enough business for one agent to impose the exclusivity of sales. Migrant entrepreneurs, on the other hand, tried to work with as many shipping companies as possible to boost their prestige and increase their business. To retain the agency, agents needed to spread their sales between the companies represented, yet the shipping company offering the best facilities and the highest commission was likely to get most of the business.

When selling a prepaid ticket, the intended passenger was given one year to make the crossing. The agent contacted the migrant broker with information about the passenger and the ticket number. The migrant broker, in this case Morris \& Co, then arranged for the transport with the HAL. The passenger could rely on the assistance of agents in his home region and at major transit points to forward him to the port of departure. Through this network, companies could arrange for this to be done according to the sailing dates, minimizing the time spent at the port and cutting down on the extra costs for the passenger. Prepaid ocean passages were generally sold together with railroad tickets to the port of embarkation and from the port

\footnotetext{
16 Van der Valk (1976, p. 156).

17 Day (2002, p 67), Wadhwani (2002, pp. 42-43).
} 
of arrival to the final destination, on which migrant agents earned an extra commission. In 1885 the Dutch company ended its association with Morris \& Sons. These steps towards vertical integration allowed the company to cut down on the commission paid to Morris, but more importantly, allowed them to increase the control over the migrant agents by dealing with them directly. Subsequently the company opened its own agencies at key transit points on both sides of the Atlantic ${ }^{18}$. However, HAL's success depended largely on the simultaneous attempts made by the steam-shipping companies to form durable and effective horizontal alliances. These were as much a matter of gaining control over the transatlantic agent-network as a means of neutralizing competition between shipping companies.

Keeling pointed out that the incentives for cartelization in migrant transport proved to be stronger than in the case of freight transport because the underlying demand was both more sensitive to economic swings and less dependent on transport prices. Economic downturns had bigger impacts on migrant flows than on freight movements ${ }^{19}$. The first conference regulating part of the American prepaid and return ticket market goes back to 1872 with the establishment of the New York North Atlantic Steam Traffic Conference. The agreement between British lines, which dominated the market at the time, covered the regulation of the agent network and transport prices. It also needed to fend off growing continental competition, especially from HAPAG and NGL which managed to threaten British dominance. After the American Civil War many new lines of various nationalities were founded, yet they never caught up with the biggest German and British firms which dominated the market. Competitors for the trade organized themselves around this rivalry. To strengthen their competitive position the German companies tried to unite lines transporting migrants directly from the European mainland to the US in a similar fashion to their British rivals. The first lasting Continental Conference was established in 1885. The conference in New York was the result of a parallel agreement signed by the directors of the companies to regulate the business in Europe. The New York sub-conference was thus dependent on the agreements in Europe. The HAPAG, NGL, RSL and HAL had already tried to join forces in 1883, but direct outside competition from the Carr Line in Hamburg and the White Cross Line in Antwerp meant that the agreement lasted a few months only ${ }^{20}$. Under the pressure of subsequent dropping migration rates, the British North Atlantic Steam Traffic Conference also folded ${ }^{21}$. A general

18 Such as Amsterdam, Leipzig, Paris, Vienna in Europe and Chicago, Boston, St. Louis, Minneapolis, San Francisco, and New Orleans in the US.

${ }^{19}$ Keeling (1999b, pp. 199).

20 Carr Line and White Cross Line were quoting lower rates and paying higher commissions, luring passengers away from the members. GAR, HAL, 318.02, 112, Letter November 21 1883. Birgit Ottmüller-Wetzel mentions another failed attempt in 1884. See Ottmüller-Wetzel (1986), p. 155.

21 Hyde (1975, p. 103). 
rate war broke out making prepaid prices fall from at least $\$ 18$, depending on the line and the service, to anywhere between $\$ 6$ and $\$ 12$, meaning at cost or at a loss ${ }^{22}$.

After long negotiations, while HAPAG and RSL took measures to neutralize the competition in their home ports, the Continental Conference reorganized in May $1885^{23}$. The agreement included minimum rates to New York based on the quality of service (see Figure 1). The HAL, running the oldest and slowest steamers, obtained differentials to their advantage. The RSL service to Philadelphia and the NGL service to Baltimore were also included in the agreement. Rates were lower on these less popular routes and fares could only be changed if the differentials were maintained. The prices quoted were gross ocean fares, including commissions. Charges for overland travel could not be included and rate sheets of continental overland fares had to be sent to the secretary. The New York representatives held monthly meetings at which decisions required unanimous support. The agent commission was set at $\$ 3$, covering all expenses except advertising in newspapers. A General Passage Agent for the Pacific coast, Western States and Southern States was appointed who had to defend the company interests in these regions and supervise the local agents. They could only represent one company, but in exchange received a commission of one dollar on each ticket sold by an agent in their area. The cancellation fee for a ticket was set at five percent. Advertisements could not contain comparisons with services offered by members of the conference. The companies also agreed to withdraw advertisements from any newspaper that attacked a member. Every breach was reported to the Secretary who, if necessary, passed on the complaint to an Arbitrator. The latter was empowered to look into the books of the companies and his decision was final. To ensure commitment to the agreement, the lines deposited a bond. The agreement was valid for six months and withdrawal was possible with one month's notice ${ }^{24}$.

A circular was sent to the agents notifying them of the conference regulations. No returns or divisions of the commission could be given, nor could improper inducements be offered to purchasers of tickets. Agents were neither allowed to engage sub-agents or runners, nor to share commissions

22 The cost for transatlantic steerage passengers was approximately $\$ 10$. Van den Toorn mentions gross prices of $\$ 12$ for the HAL and $\$ 10$ for the German lines while Huldermann quotes rates of $\$ 6$, without specifying whether they are gross or net rates. GAR, HAL, 318.02, 112, Letter January 16 1886. See Huldermann (1922, p. 22).

23 The Union Line merged with Carr Line and reached a pooling agreement with the HAPAG, neutralizing the competition between Hamburg Lines. With the agreement, Albert Ballin made his entry into the HAPAG. He became the driving force behind the expansion of the conference system. In Antwerp the White Cross Line lost ground on the RSL and had to discontinue its passenger service a short time later. See Ottmüller-Wetzel (1986, pp. 150-157).

${ }^{24}$ GAR, HAL, 318.04, 563, "Articles of an agreement entered into by and between the managers of the Continental Lines for the purpose of regulating rates of passage and the business connected therewith May 15 1885» and minutes of the Continental Conference 1-27. 
with third parties. The actual amount received for the passage had to be stated on the ticket and no credit could be given to the purchaser. Shipping companies only paid commission on the actual issue of the ticket and the direct receipt by the agents of the passage money. Agents were not allowed to issue certificates, orders or tickets for prepaid passage drawn on any person or company other than the lines actually employing such agent. The selling of tickets was restricted to a certain area which prevented agents from invading each other's territory. Violations of other agents had to be reported, with evidence, to the secretary. The punishment depended on the infraction and could vary from a minimum fine equal to the price of the ticket to the disqualification of the agent. Agents who did not comply with the agreements would be disqualified and lines agreed not to re-engage any dismissed agents. On paper the agreement looked very promising, in practice it would prove very difficult to implement.

\section{THE WORKING OF THE CONTINENTAL CONFERENCE UNTIL THE FORMATION OF THE NDLV}

The evolution of ocean rates serves as a good indicator of the cartel's success. To what extent were the companies able to raise prices? To what extent did they overcome external and internal pressures? Applying Osborne's model to this case, the external problem can be reduced to the ability of the lines to predict and limit the market share of outsiders to keep the agreements viable. Internal problems consisted firstly of finding a workable and profitable contract; secondly of making sure that the agreement generated the expected shares for each member and thirdly the ability to detect and deter cheating. For both Osborne and Stigler, the detection of cheating plays a crucial role in collusion. Secret violations of the agreement, especially in the form of price cuts, gave shipping lines the possibility to increase their market share. According to Stigler, if the means of detection were weak, prices could not rise much above the competitive level. The basic method of detection was to note when price cutters were obtaining business which a line did not otherwise obtain ${ }^{25}$. Information on the market share of each line was readily available as American ports registered all incoming third class passengers. Fluctuation in sales of migrant agents in certain regions also served as a barometer. Yet the biggest problem was to prove that lines obtained the increased share by cheating. The next section consists of an analysis of the external and internal pressures during the first seven years of the cartel until the division of the market into shares with the formation of the NDLV.

${ }^{25}$ Osborne (1976, pp. 835-844), Stigler (1964, pp. 44-61). 


\subsection{Harmonizing the external pressures}

\section{The connections between British-Scandinavian, Continental and Mediterranean markets}

The external pressures on the conference were considerable. The European migrant market was divided into three sub-markets; the BritishScandinavian, the Continental and the Mediterranean (see Appendix 1). The British-Scandinavian market was predominantly in the hands of the British lines. The British Board of Trade imposed extensive controls on Continental ships which meant that these vessels were not permitted to transport British and Irish migrants from the Isles on the westbound voyage ${ }^{26}$. This internal market represented the majority of the revenues of the British lines, which had a strong foothold in the Scandinavian market through well established feeder services, such as the Hull-based Wilson Line ${ }^{27}$. Despite the geographical advantage and continuous efforts of the German lines and the Copenhagen-based Thingvalia Line to increase their market share, the majority of Scandinavians preferred to travel on British ships. Attempts to convince British and Irish migrants to emigrate from continental ports were even less successful. Conversely, the British lines had always been able to attract continental passengers to travel indirectly through British ports. The strong trade relations between Hamburg and England during the early years of mass migration transformed Hamburg into the most important hub for indirect transatlantic migration ${ }^{28}$. The ties between migrant brokers and agents in Liverpool and Hamburg were well established and institutionalized by British and Hamburg Senate laws ${ }^{29}$. These ties constituted the Achilles heel of the Continental Conference. Although continental traffic only represented a small percentage of the total business of British lines, it allowed them to exert constant pressure on the continental lines which were, to a large extent, dependent on the goodwill of the British lines to raise their prices or lower commissions for continental traffic ${ }^{30}$. The

${ }^{26}$ Murken (1922, p. 58).

7 Brattne (1976, pp. 176-200), Evans (2007, pp. 52-55), Hyde (1975, pp. 60-62).

28 See Engelsing (1961), Gelberg (1973, pp. 10-13). Unlike Bremen, the Hamburg authorities initially opposed the migrant trade. Only during the 1840s did the Hamburg merchants realize the importance of the trade. The lag of interest in direct transatlantic transport from Hamburg and the long-established trade relations between British ports and the Hanse town favored indirect migration. Indirect migration through Rotterdam quickly decreased once the HAL was established (Van der Valk, 1976, p. 162). The Inman Line had to stop its feeder service from Antwerp immediately after the opening of the RSL (Flyhart, 2000, p. 113). HAPAG, the biggest shipping company worldwide at the turn of the century, was never able to put an end to indirect migration through its home port (Broeze, 1992, p. 1).

${ }^{29}$ Hamburg Staatsarchiv, Consulaat Liverpool: Auswanderungsangelegenheiten 1851-68 nr 8.

30 In 1894 the British market share of steerage passengers was 70 per cent English and Irish, 22 per cent Scandinavian and 8 per cent Continental passengers. GAR, HAL, 318.04, 223, May 91894. 
government protection of their internal market, as long as they had a foothold on the continent, gave the British lines the edge over their Continental rivals.

The Mediterranean market, which at the time was starting to grow, consisted mainly of Italians. Some companies, such as the Fabre and Italian Line, opened a direct service to New York. Other British and Continental lines also tried to lure Italians to their ports. In particular, the French line, Compagnie Générale Transatlantique (CGT), which drew migrants mainly from South-West Germany and Switzerland with special railroad services, saw the Italian market as the most natural territory for expansion ${ }^{31}$. The company increasingly centered its efforts on the Mediterranean and Oriental markets which boomed later in the mid 1890s leading to the opening of new direct services. At one of the first meetings of the Continental Conference it was decided that direct and indirect lines should try to unite in a Mediterranean conference to fix through rates for this region ${ }^{32}$. In the same year, RSL and HAL took the initiative to form the Mediterranean Conference with the Fabre and Italian Line. If rates for Italian destinations differed significantly from continental ones, Swiss and Austrian migrants might choose them instead of using continental ports. If Scandinavian rates were lower than continental rates, Germans and Poles would be booked at the lowest price. If the rate difference between the continent and the British Isles was too large, migrants from the continent would travel to Liverpool, which offered frequent services to many continental destinations. In short, the different conferences were dependent on each other to increase rates jointly.

\section{Outside rivals on the Continent: Thingvalia and French Line}

The Continental market ranged from Spain to Russia and was in full expansion to the east at the time. The Continental Conference had been drawn up to include both Thingvalia Line and CGT. The Danish line focused on the Scandinavian market but the location of Copenhagen allowed them to target the continental market easily. However, the Danes could not be convinced to join the conference. The non inclusion of the CGT had greater repercussions on the working of the conference. Having, to a great extent, the same hinterland as the members of the conference, they could not fix rates and commissions that differed much from the CGT without risking the loss of a share of the traffic. Moreover, the British lines required that the CGT be included in the conference in order to raise rates jointly. After months of futi-

\footnotetext{
31 De Vannoise-Pochulu (1993, pp. 10-17).

32 GAR, HAL, 318.02, 112, Letter January 161886 and GAR, HAL, 318.04, 563, May 251885 , minute 41 .
} 
le negotiations, the Continental lines increased ocean rates by $\$ 2.5$ while taking measures to force the CGT to join the conference. The conference members did not use so called «fighting ships», a practice consisting of announcing special sailings at drastically reduced rates whenever an outside line scheduled a departure ${ }^{33}$. Neither did they cut the ocean rate affecting all continental business. Instead they cut railroad rates to popular destinations of the French line's traveling public. The lines also matched the CGT's increased commission of $\$ 4$ on eastbound tickets. Furthermore, agents were notified that unless they relinquished the agency of the French line, ticket books of the Conference lines would be withdrawn from them ${ }^{34}$. This forced the CGT to rely on the disreputable yet very active parallel network of non-conference agents. The British lines also helped to put pressure on the French to enter the conference through the agent network ${ }^{35}$. Negotiations resumed and the CGT entered after reaching an agreement with the RSL and HAL regarding through rates, including the railroad fare to points in Switzerland, France and Northern Italy. This cleared the path to enter further negotiations with the British lines on rates and agent regulations.

\section{The network of migrant brokers and agents: the concentration in New York}

One of the priorities of the Continental Conference was to impose «city rules» in New York. European migrant brokers and agents had to apply to the authorities for a concession which was obtained after depositing a bond. European laws assisted their shipping companies to gain control over the migrant agents. In the US no laws regulating ocean passage sales existed. The agent network was left to the sole supervision of the passenger lines. On the American market most ocean passage tickets were sold in the city, where chaos reigned because of the proliferation of agents and runners ${ }^{36}$. Innkeepers, boardinghouses, peddlers, etc. sold tickets over the counter which they obtained from migrant agents. With «city rules» the lines wanted to do away with the middleman and restrict the sale of ocean tickets in New York to the company's office. This would greatly increase the control over the business and eliminate commission costs. However, to achieve this without important losses of market share, all the lines had to adhere to the system. Once the British reached their provisional agreement,

${ }^{3}$ By sharing costs, conferences often used this strategy to drive an outside line off a certain route or force them to enter the agreement.

${ }^{34}$ GAR, HAL, 318.04, 563, May 31, minutes 39; July 15, minute 63; August 20 1885, minutes 74,85

${ }^{35}$ GAR, HAL, 318.02, 112, Letter January 161886.

36 About 80 percent of European migrants arrived in New York. Emil Boas, New York head agent of the HAPAG testified before the Ford congressional committee that 75 per cent of the prepaid and return tickets were also sold in New York (see New York Times: «Beginning their labors» June 26 1888). 
the members of the Continental Conference greatly reduced the number of agents in the city. However, they awaited the collaboration of the other lines to move forward into the market and take over sales in the city ${ }^{37}$.

The lines also wanted to counter the developing system of orders with the "city rules». European cash rates were inferior to American prepaid rates, while the agent's commission was higher in Europe making the net ocean fare in Europe significantly lower ${ }^{38}$. Midway through the 1880 s some American agents started selling their own orders for steerage passage drawn on European agencies at cash rates, allowing them to undercut the continental prepaid rate by up to $\$ 4$. These orders were then exchanged for European cash rate tickets of the shipping companies by the agency in Europe. This practice started in Hamburg where British lines stimulated the order system to increase their continental market share. HAPAG informed conference members that unless the British lines could be forced to raise the European cash rates, they would have to break up the prepaid rate agreement to meet said competition ${ }^{39}$. The German line opened a low cost New York-Baltic service to and from Copenhagen, Göteborg and Stettin to put pressure on the British lines, while in the meantime it negotiated with the migrant brokers in Hamburg ${ }^{40}$. By the end of 1886 the British lines, HAPAG and Hamburg migrant brokers had reached an agreement. The German line withdrew its direct Scandinavian line while the British lines agreed to limit their share of the traffic going through Hamburg to 35 percent. The price difference between indirect and direct routes could not exceed five Marks to the advantage of the British lines. A Clearing House was set up to control traffic through Hamburg ${ }^{41}$.

Although an agreement was reached that agents of all three conferences could make bookings for all members excluding outside lines, the distrust between the German and British lines remained, impeding the imposition of city rules and a significant price rise. The payment of secret extra commissions persisted ${ }^{42}$. When, at the beginning of 1888 , tensions seemed to be under control as the commission was jointly lowered to $\$ 2$, price changes were mutually discussed by the conferences and the imposition of «city rules» was considered, the Mediterranean Conference fell apart. The

37 GAR, HAL, 318.04, 563, May 25 1885, minute 38; January 25 1886, minutes 164-166.

38 The difference varied constantly. In January 1890 the difference on net ocean rates was $\$ 4.7$ with prepaid tickets at $\$ 19$, while Hamburg cash rates were at 60 Marks. In July 1892 the difference was reduced to \$1.6. GAR, HAL, 318.04, 221, Letter January, 201890 and GAR, HAL, 318.04, 222, Letter July 151892.

39 For instance, in early 1886 the British cash rate stood at $\$ 18$ against HAPAG's prepaid rate of $\$ 25$ giving the British lines a differential of $\$ 7$. GAR, HAL, 318.04, 563, March 291886 , minute 197.

40 Ibid., June 26 1886, minute 250.

41 Murken (1922: 19), Otmüller-Wezel (1986: 195).

42 Ibid., Circular to agents April 14 1887; May 31, minute 31, June 26, minute 50, August 15 1887, minute 61, September 6, minute 64 and September 201887 minute 69-70. 
Arbitrator found RSL guilty of cutting rates and giving special incentives to agents, upon which the Fabre and Italian Line decided to leave the Mediterranean Conference. The interference of the Italian government, which passed laws aimed at directing traffic through national ports, hindered renegotiations. It also put an end to plans to pool the Mediterranean market and open joint offices in New York where all lines would have been represented by an independent agent whose books would have been accessible to members at all times ${ }^{43}$. Subsequently, the agreement between the British lines was also discontinued due to internal tensions leading to a rate war on the British-Scandinavian market. The Continental lines managed to prevent rate wars from spreading to the continent but could not prevent them from bringing down rates ${ }^{44}$.

\subsection{The internal pressures}

\section{Internal distrust, duration of agreements and constant renegotiations}

Distrust between members who for a long time had seen each other as their main rivals constantly weighed on the Continental Conference. The underlying suspicions are reflected in the duration of the agreements. During the first five years, agreements were never renewed for longer than seven months ${ }^{45}$. Sometimes the negotiations to renew an agreement, during which the old agreement usually continued, took longer than the duration of the agreement itself. With fixed prices the competition between the lines moved increasingly towards the quality of service. During the first five years, the HAL in particular greatly improved its fleet ${ }^{46}$. As differentials between lines were based on quality of service, they were subject to constant renegotiations. The RSL insisted that initial differentials should be adapted accordingly ${ }^{47}$. These tensions quickly led the conference into its first crisis less than a year after its creation.

Failing to obtain its expected market share, the RSL refused to renew the agreement triggering a rate war in which prepaid fares plummeted by $\$ 10$.

43 Ibid., October 25 1887, minute 77; January 31 1888, minute 165; October 2 1891, minute 370, GAR, HAL, 318.04, 221, Letters January 3, 20 1888; September 10, October 3, 17 and November 191890.

44 Ibid., July 16 1889, minute 165; October 2, minute 370; December 2, minutes 375-379; December 23 1890, minute 382 and GAR, HAL, 318.04, 221- 222; Letters October 11, 15 1889; January 211890 and December 101891.

45 Only once, in 1889, were agreements renewed for a year. GAR, HAL, 318.04, 221, Letter December 111889 .

46 Between 1886 and 1889 the HAL bought seven second-hand ships, totaling 27.000 tons.

47 GAR, HAL, 318.04, 563, December 11 1888, minute 214; June 13 1889, minute 273. Eventually the HAL gave in and agreed to reduce the rate differential with the RSL by 50 cents. GAR, HAL, 318.04, 221 Letter October 111889. 
The HAL reacted by notifying its agents that it would meet any new reduction of the RSL to maintain the rate differential it had before the rate war. Conference agents were at liberty to dispose of their commission as they saw fit, yet had to stop selling RSL tickets or send back the ticket books of the Conference lines. The limit on the number of agents in New York was lifted ${ }^{48}$. This rate war to force RSL back into the fold lasted eight months during which agents were allowed to disregard many regulations. When they were caught violating the rules still in force, fines were lower. Agents caught selling tickets for the RSL first received a warning before being disqualified, to prevent as many agents as possible from giving up the conference agency. With the new agreement, a circular was sent to remind agents of the regulations and add some new ones. These included the increase of cancellation fees to ten percent and the replacement of fixed commissions with commissions of ten percent of the price of the ticket. The latter could have moved agents and ship-owners towards a common interest in raising prices. Yet the small lines feared that the percentage basis would stimulate the sale of the more expensive services of the bigger lines. Their protests eventually led to the reintroduction of fixed commissions. This was only one disadvantage of the lack of product homogeneity.

\section{The lack of product homogeneity: various services, destinations at different rates}

The working of the cartel was further complicated because some lines offered slow and fast services and also to different ports of arrival such as, Baltimore, Philadelphia and New York at different rates. Negotiations concerning whether to include new services added to the internal tensions. For example, the HAL opened a Baltimore service because of its cheaper railroad rates to and from the West, the more lenient implementation of immigration laws and to fight the increasing competition for freight between Rotterdam and the US ${ }^{49}$. Yet the Dutch line was also the only company with just one destination and no variety in standard of service. It was a well known practice for companies to book passengers for a regular service to be transported on express steamers, or passengers were booked at lower Philadelphia and Baltimore rates but landed in New York. Although this was against the conference rules, it was very difficult to prove such abuses. Companies gave these facilities to their most reliable agents who, to avoid fines and possible disqualification, operated in the utmost secrecy. As pas-

\footnotetext{
${ }^{48}$ Ibid., 563, July 26, minute 258, August 2 1886, minutes 265-269 and ibid., 767, Circular to agents August 31886 .

49 In 1890, rates from Baltimore to the West were, on average, $\$ 1.94$ cheaper than from New York. Tickets from Philadelphia cost on average $\$ 1.24$ less than from New York. Ibid. 221, Letter, December 201890 .
} 
sengers were very reluctant to give affidavits regarding fraud, the lines hired private detectives when they suspected a member of evading the regulations on a large scale. They pretended to be clients yet all kinds of tricks were used to prevent them from getting their hands on evidence ${ }^{50}$. To prove cheating with upgraded services, the detectives had to actually travel on these tickets.

Whenever the violations of the agreement were too difficult to prove, the Dutch line made sure to be able to tamper with them as well, explaining the opening of the Baltimore service. The NGL, which practically monopolized passenger traffic in Baltimore, radically opposed the inclusion of the new service in conference agreements. In theory it meant that conference agents were not allowed to book for the HAL's Baltimore service. In practice, by paying extra commission the HAL found many agents willing to take the risk of being fined or disqualified, since they had means to prevent other lines from obtaining proof of the violation. Not having to comply with conference rules permitted the HAL to undercut NGL rates significantly and pay higher commissions thus attracting a fair share of passengers ${ }^{51}$.

\section{Agreements on ocean rates intensified the competition on railroad rates}

Fixed ocean rates intensified competition on railroad rates as rail travel and ocean passages were often sold together. The differentials on ocean rates, resulting from tough negotiations, could easily be cancelled out by railroad fares. Trying to fix through rates, the conference secretary required the lines to hand in lists of actual overland fares obtained from transport companies on both sides of the Atlantic. Any cut in these rates was considered a conference violation yet, once again, it was very difficult to provide evidence of this. The lines constantly negotiated with railroads to obtain special rates in exchange for their business. On American soil the lines used the keen competition between the railroads to obtain all kinds of reductions. Yet, with the establishment of the Immigrant Clearing House, coordinating the immigrant railroad transport, in 1887, the railroads increased their rates and cut the commissions granted on railroad tickets sold in connection with ocean passages. Special reductions persisted, yet these were far less significant ${ }^{52}$.

European overland tariffs caused greater instability. The HAL's low overland tariff had a particularly demoralizing effect. The Dutch railway and the Rhine steamboat companies reduced their fares in 1887 giving the HAL an

50 At some stage the HAL had to hire an extra bookkeeper to cover up the violations of the agreements. Ibid., 222, Letter August 211891.

51 Ibid., 222, Letters March 17, June 12, July 22 and September 251891.

52 See Feys (2007p: 245-272). The appointment of a special committee to put an end to rate cuts on railroad tickets sold in connection with eastbound ocean passage shows that the problem persisted. Ibid, 563, December 22, 30 1890, minute 384, 390. 
important differential on overland transport. The other members questioned the validity of these rates and brought the case to the arbitrator. While awaiting his decision, members ignored the rule which required lines to quote the actual overland tariff and offered HAL's rates. Tensions increased when the arbitrator ruled in favor of the HAL and the RSL refused to stop using the HAL tariff ${ }^{53}$. The Dutch line attributed the low rates to the geographical advantage of Rotterdam which it was not prepared to give up. After long negotiations, the companies reached a compromise, reducing the differential on ocean rates between lines ${ }^{54}$. Even with this arrangement, the CGT calculated that the average differential, including railroad and ocean rates, at thirty five popular locations in Europe amounted to $\$ 9.25$ in favor of RSL and \$11.35 in favor of HAL. To prevent the French line from leaving the conference, the HAL and RSL reduced differentials on through rates to French, Swiss and Northern Italian destinations to $\$ 2$. A special sub-committee was formed to tackle the problems of European overland fares by establishing a list of a maximum of 300 points where passengers could be booked through at fixed rates ${ }^{55}$.

\section{The takeover of the prepaid market by migrant brokers}

The most important internal pressure was the competition between lines to obtain passengers from the migrant brokers by giving them special facilities. This allowed the predominantly Jewish entrepreneurs to completely corrupt the prepaid market out of Hamburg through their own orders with the line's consent. The pool agreement for the Hamburg traffic between HAPAG and the British lines did not put an end to the practice. The difference in price between the net cash and prepaid rates was between $\$ 4$ and $\$ 5$. After repeated requests from New York head-agents, the gap was reduced to $\$ 2.5^{56}$. Yet this still offered enough margin for Hamburg migrant bro-

53 Ibid., May 31, minute 32; November 17, minute 87; December 27 1887, minute 104; January 31, minute 109; April 24, minute 143; July 2 1888, minutes 174-176.

${ }^{54}$ Ibid., January 22 1889, minute 224 and GAR, HAL, 318.04, 221, Letters June 16 and 22 1888 .

55 Ibid., June 27 1889, minute 272-276; February 27, minute 329; December 30 1890, minute 390; May 21, minute 432; July 1 1891, minute 449.

56 Unfortunately no price series of European cash rates is available but additional commissions and the price difference must have been around $\$ 4$ to $\$ 5$, based on the repeated calls of the agents to raise the cash rate by ten to fifteen Marks or cut prepaid rates by $\$ 2$ to $\$ 3$. In 1889 the CGT was still urging for a reduction on prepaid rates of $\$ 3.5$ despite a previous rise of the cash rate by 10 Marks. In 1890 the gap between net prices was further reduced still leaving a difference of $\$ 2.9$; the cash rate being 60 Marks, which at the contemporary exchange rate used by the companies of 4.2 Marks to the dollar brings it to $\$ 14.1$ while the prepaid net rate was $\$ 17$ or 72.1 Marks. GAR, HAL, 318.04, 221-223, Letters of Van den Toorn and ibid., 563, October 25 1887, minute 72; February 28, minute 127; June 16 1888, minute 165; meetings March 10; April 10; May 2 and 101890 . 
kers, who in the meantime had opened branch offices in New York, to undercut the prepaid rate. Although it was against the conference rules, it was a public secret that the HAPAG reached special arrangements with some brokers using their own orders to counter the competition of the British lines in its home port. Because of this rivalry, the practice spread quickly and other Continental lines made arrangements through branch offices in New York to get their hands on the order business. Instead of imposing «city rules» and closing the gap between shipping companies and clients, the discord between lines allowed these brokers to take control of ocean passage sales. They drove migrant agents selling regular prepaid tickets out of business. Therefore many agents started selling the brokers' orders instead of regular tickets. When caught cheating, offenders paid the fine, protesting against the pending disqualification for a subsequent offence and claiming that the conference gave no protection to regular business. By 1889, the CGT, which because of its orientation towards the Mediterranean market did not have the same connections with Jewish migrant brokers who initially specialized in the Eastern European market, saw its continental prepaid sales come to a standstill ${ }^{57}$.

During the next eight months, lines renegotiated the agreements allowing Jewish brokers to increase their grip on the market. The order business spread to Baltimore, Philadelphia, Chicago, Saint Louis and Milwaukee. Because of the restrictions of the Hamburg pool, brokers opened branch offices in Bremen, Rotterdam and Antwerp to expand their business. Migrant brokers, such as L. Scharlach for the HAL, F. Missler for NGL and S. Jarmulowsky for the RSL, obtained control over the prepaid business. To increase their market share the companies gave all sorts of facilities in violation of conference agreements, ranging from cheating with upgraded service, to not charging cancellation fees, paying extra commission, allowing the change of names on the ticket, hiring subagents, dividing the commission or offering part of it as a reduction to the buyer. The Hamburg pool, created to control indirect migration through the port, boomeranged with the opening of new indirect routes, increasing tensions between continental members and with British lines. Much to the dislike of the HAPAG, the RSL and HAL had to be included in the Hamburg pool to prevent the abuses from escalating. The HAPAG saw its share of the traffic through its home port further reduce. Tensions between HAPAG and HAL accumulated to the extent that both made preparations to let their ships go through each other's home port. Conference agreements failed to provide the desired stability and unless members found a new arrangement, a general rate war seemed unavoidable ${ }^{58}$.

\footnotetext{
57 Ibid.

58 RSL and HAL, the former eternal rivals, joined forces to strengthen their negotiating position against the German line. On the admission of the pool, lines had to stop giving extra com-
} 


\subsection{An evaluation of the first seven years of the Continental Conference}

The interdependence between the shipping conferences dividing North Atlantic passenger traffic into three sub-markets to raise prices, fix commissions or implement conference rules governing the network of agents undermined the stability of the Continental Conference. The cartel managed to prevent rate wars in other sub-markets from spreading to the continent, yet these prevented the lines from significantly raising fares to avoid continental passengers from taking alternative routes. With their foothold in Hamburg, the British lines managed to maintain the upper hand. The HAPAG's efforts to neutralize this competition in its home port backfired and also affected the internal cohesion between Continental lines. The lack of an efficient means of detecting and discouraging cheating on the agreements, especially those regulating sales through the migrant agent network, hampered the efficiency of the cartel. Instead of becoming more transparent, transactions became even more corrupt. Where violations of the agreement were too difficult to prove, members made sure they were able to cheat on them as well, encouraging abuses. Most evidence of cheating was collected by companies' personnel and private detectives. Yet the cost of detectives, who found it difficult to get their hands on affidavits, proved an inefficient way to verify cheating. Agents hardly ever denounced colleagues. Cheating was widespread and most agents were not irreproachable, which removed the incentive to denounce. Shipping companies were not able to implement the rules designed to eliminate differential treatment of customers by migrant agents. Neither could they prevent themselves from only awarding facilities to some brokers and not others. When violations by agents were recorded, the conference failed to use retaliation to deter repetition. Fines were not high enough while lines refrained from disqualifying most agents fearing that they could do more damage by working for nonmembers ${ }^{59}$. Members caught cheating also got away with a moderate fine too easily, while Van der Toorn observed that this only had a slight effect on the line's position during the next renegotiations of the agreements. These circumstances prevented the companies from raising gross prepaid rates.

mission to their Hamburg agency but were assured a fixed number of passengers or compensation if the number was not reached. As Van den Toorn observed, the number of passengers would decrease but they would be booked at a better price. Moreover the Hamburg pool was an excellent means of putting Ballin under pressure during negotiations. With the agreement HAPAG saw its share of the traffic through Hamburg decrease from 65 per cent to 57,8 per cent. GAR, HAL, 318.04, 563, August 29, minutes 284-285; September 17, minute 291; October 81889 , minute 298; January 23, minute 317; February 27 1890, minute 328. Ibid., 221, Letter October 2; November 19 1889; January 31 1890. Ibid., 221, Letters July 30, August 19 and September 10 1890; June 8; July 14; September 121891.

59 For instance, the conference disqualified L. Scharlach twice, yet both times he fought his way back in. 
FIGURE 1

NEW YORK PREPAID FARES OF CONTINENTAL LINES 1885-1892

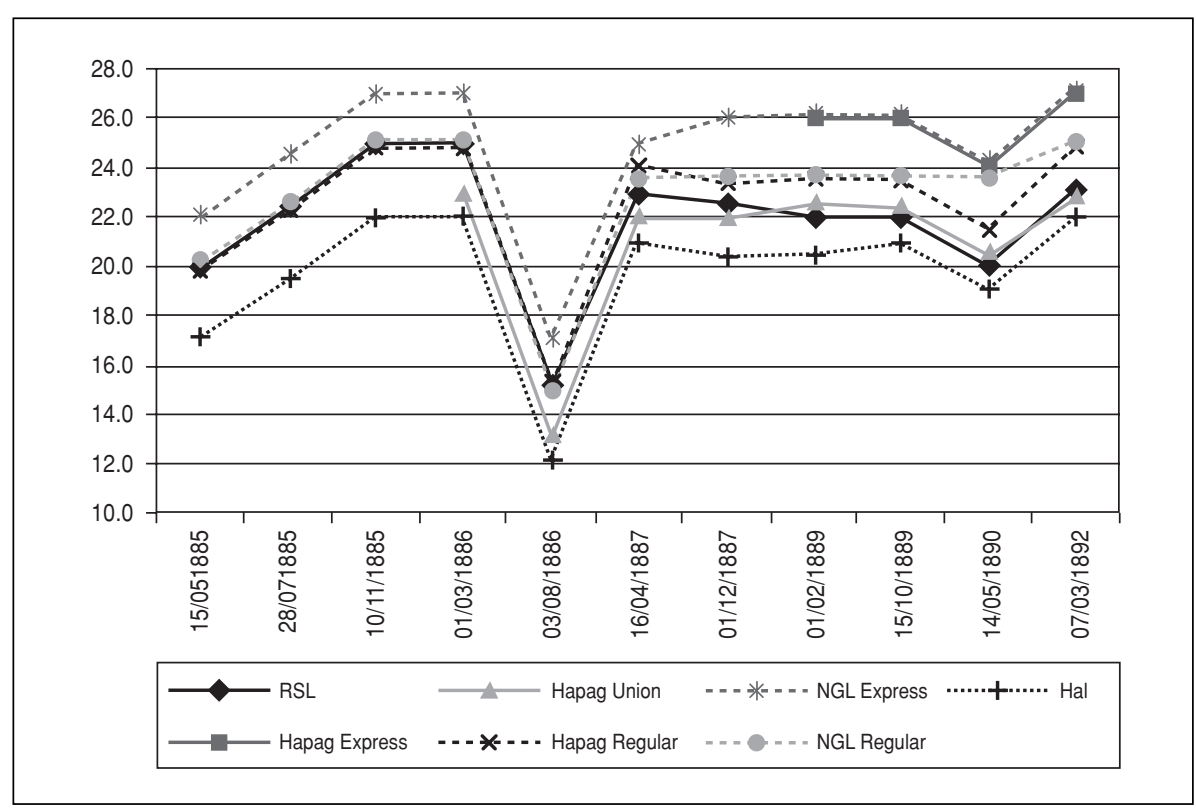

The cost per passenger was approximately $\$ 10$, yet taking cheating through cheaper European cash orders, payment of extra commissions and cuts on railroad rates into account, the HAL's net prices can only have exceeded this cost slightly. These indirect price cuts varied according to the competitive pressures causing net rates to be far less stable than the figure showing gross rates suggests. The conference failed to increase the Dutch line's profits while, in the meantime, it invested heavily in its fleet. This worked to the advantage of the agents and especially of the migrants. Extra commissions were often returned to passengers to enable agents to increase their sales. Hence migrants enjoyed better and faster services at rates barely covering costs.

\section{POOLING THE TRAFFIC, THE TONNAGE CLAUSE AND THE IMPACT ON CONFERENCE AGREEMENTS}

Fixing market shares was the most efficient method of combating secret price cutting ${ }^{60}$. The initial years of the Continental Conference convinced

60 Stigler (1961, p. 44-61). 
members of the need to reduce the competitive pressures to control both agent networks and transport fares. Albert Ballin, manager of the HAPAG, which suffered most of the instability, became the driving force behind the expansion of agreements. Core members divided the market into shares and used compensation schemes to balance shortages or excesses. To reduce external price cutting, agreements were made with other lines to divide the North-Atlantic market geographically. Although simultaneously the American anti-trust movement gained momentum, shipping lines felt protected by the knowledge that American jurisdiction did not extend to international waters. This belief vanished midway through the 1890 s, yet did not affect conference negotiations during the period analyzed here.

\subsection{The formation of the Nord-Atlantischer Dampfer-Linien Verband}

Negotiations for a westbound pool between RSL, HAL, NGL and HAPAG started early in 1890 . As CGT refused to join these talks, the members considered France, Switzerland and Italy as special territories for which they organized a separate "Money-Pool» ${ }^{61}$. The situation in Hamburg made the inclusion of the British lines highly desirable, if not indispensable. Market shares were based on the number of continental steerage passengers carried in the previous decade from ports north of Cadiz to the US and Canada, giving the HAL a share of 8 per cent, RSL 13.5 per cent, NGL 39.7 per cent and HAPAG 24.8 per cent. A separate contract with the British lines limited their share to 14 per cent. The percentage participation could be altered depending on changes in tonnage of vessels employed by either more frequent use or the introduction of new vessels. Companies which exceeded their percentage had to compensate the lines which fell short with a fixed amount per passenger which depended on the ocean fare. To limit these compensations, members with a surplus during the year would raise their rates to allow companies short of their share to book passengers at more profitable prices instead of having to lower theirs. Gross rates and agent commissions were fixed; anywhere between 6 and 20 Marks in Europe, $\$ 2$ to $\$ 5$ in the US. Members agreed that prepaid gross rates should, as far as possible, be equal to European cash rates. No commission was allowed on overland European transport which was limited to 300 popular departure points. All members paid high deposits as a disincentive for lines to drop out of the agreement. The contract was valid for four years. Only if alterations proposed by two members or more were objected to, did a company

${ }^{61}$ The lines contributed a fixed amount per passenger transported from these territories which was then divided into shares at the end of the year. The CGT did remain in the New York Conference adhering to the rules and adapting the rates in accordance with the members' interest. GAR, HAL, 318.04, 221, Letter January 291892 and ibid., 563, April 1 1892, minute 537. 
have the right to withdraw from the agreement ${ }^{62}$. As observed by Van den Toorn, there was a lot of apprehension among members regarding the outcome:

No one knows what the pool will bring and why HAPAG was so compliant with the NGL. Possibly it is a conspiracy to destroy us and the $R S L$, however I'd rather believe that both urgently need money and want to clear out the steerage business from innumerable abuses, being weighed down by the restless actions of agents, or should we say parasites ${ }^{63}$.

The contract shows that the members learned from the weaknesses of previous agreements. The quotas warranted that rates would no longer be cut to obtain a larger market share. Linking prepaid with cash rates had to bring an end to the order-system. Efforts were made to fix rates for overland travel and HAL's Baltimore service was included. The duration of four years without notice put an end to the continuous renegotiations and constant threats of withdrawal. Separate agreements neutralized competition from CGT and British lines.

\subsection{The British-Jewish Hamburg Connection: the conference's Achilles Heel}

According to Van den Toorn, the collaboration of the British lines had been bought dearly, yet internal division among the members of the British Conference, which by then numbered thirteen members, delayed the signing of the contract. Moreover, the Cunard Line, in particular, distrusted the true intentions of the German lines. The American Line which, together with the RSL formed the International Navigation Company, served as platform for the negotiations ${ }^{64}$. The verbal agreement which was to be enforced in February 1892 remained pending. Two months later the lines went ahead without the National and Cunard Line for a three-month trial period. They jointly increased rates to unprecedented levels. Yet with Cunard and National lines quoting \$19 and \$15 respectively via Hamburg, while the HAPAG's lowest rate was $\$ 25$, the German line was forced to pay a secret

${ }^{62}$ GAR, HAL, 318.04, 580, Copy of contract «Nord-Atlantische Dampfer-Linien Verband» January 191892.

63 GAR, HAL, 318.04, 222, Letter December 201891.

64 Both were the result of a failed attempt by the Pennsylvania Railroad Company to divert part of freight and passengers traffic from New York to Philadelphia in the 1870s. The American Line sailed under the American flag, the RSL under the Belgian one, because of the high extra costs which entailed sailing under the American flag. See Flayhart (1998, pp. 127-135 and 2000, pp. 15-62, 91-112), Safford (1985, pp. 53-81). In this text, when mentioning the British lines we refer to the lines managing a service from British soil, thus including the American Line. 
extra commission of $\$ 3.5$ to its agents to reach their pool share ${ }^{65}$. Whatever scheme Ballin put together to increase profits for his shipping company, the money ended up in any pocket but his own. He reached special agreements with agents on the Prussian-Russian boarder and the Jewish Aid Committee of Berlin and lobbied the German government to pass laws putting an end to the Hamburg brokers' business ${ }^{66}$. It forced the Hamburg Agents' Association to negotiate a new three-year pool agreement, setting minimum rates for all lines for which they booked. Fixed commissions on cash passengers were pooled by the agents» association. A clearing house controlled the authenticity and validity of all prepaid tickets to prevent evasion from the pool through order-tickets. The margin between British indirect services and the cheapest direct HAPAG service was reduced to two Marks ${ }^{67}$. Overall, the pool produced satisfactory results and was extended to the eastbound steerage business ${ }^{68}$. When everything seemed to be falling into place, cholera broke out in Hamburg disrupting traffic for six months.

When business resumed, both westbound and eastbound pools were extended until the end of 1893 and rate agreements were reached with the British lines. In the meantime, due to the crisis in Hamburg, Jewish migrant brokers strengthened their position in other continental ports. Letting the brokers increase their influence in Rotterdam exposed the HAL to difficulties regarding indirect migration through England which HAPAG tried to control without success. Yet, as Murken underlined, some migrant brokers became more powerful than the shipping companies due to the internal rivalry between lines which the pool did not bring to an end ${ }^{69}$. Because of the ability of these brokers to direct migrants via certain routes, even if it meant extra travel and extra costs, the HAL preferred to see them settle in Rotterdam than in Antwerp. Moreover, it would promote the direct route through the Dutch port instead of via Hamburg which was too dangerous to depend on ${ }^{70}$. If the pool fell apart, the brokers were an asset in assuring part of the migrant flow to Rotterdam.

Because of the continuing distrust between the Continental lines and, more especially, the failure to include all British lines, the brokers regained special facilities from the lines which corrupted the market. HAL gave

65 GAR, HAL, 318.04, 563, April 1 1982, minute 541; ibid., 222, Letters May 11 and 271892.

${ }^{66}$ Ibid., 221, Letters of July 1 and 151891 . Two years later the German government put the border health control stations under the supervision of the German lines. See Wüstenbecker (2003, pp. 223-236)

${ }_{67}$ Ibid., 580, Contract between HAPAG and Vereinigung Hamburgischer Passagier-Expedienten June 11892.

${ }_{68}$ Ibid., 222, Letters June 22, July 12 and August 51892.

${ }^{69}$ Murken (1922, p. 14).

70 At first the HAL directors opposed doing business with migrant brokers via Hamburg and Bremen, fearing that it would promote the Hamburg route to the detriment of Rotterdam. When, as anticipated, HAPAG found a way to bypass the brokers it would be hard to reorganize the overland journey of migrants directly to Rotterdam. 
Scharlach a special rebate of ten marks on cash rates which, added to higher commissions in Europe, allowed him to undercut prepaid tickets by $\$ 5$. Scharlach was also at liberty to change the name on the ticket, omit the price and was exempted from paying cancellation fees. This allowed him to speculate by writing out many orders when he expected prices to increase. Furthermore, if he obtained better conditions from the British lines, HAL passengers could easily be cancelled and forwarded indirectly. Scharlach quickly gained control over the HAL prepaid sales. When all British lines refused to renew the pool agreement for 1894, a rate war seemed inevitable and the brokers posed a very serious threat. Moreover, the Dutch and American authorities started applying stricter border controls on HAL passengers because Scharlach supplied a growing number of destitute migrants in poor health and in need of assistance. The company withdrew all facilities from Scharlach and retook control of the business ${ }^{71}$. Together with other migrant brokers who had been cast aside, Scharlach chartered a ship, completely bypassing the lines. Shipping companies, for their part, increasingly moved into the migrant banking and remittance market to put pressure on agents ${ }^{72}$.

\subsection{Remaining internal and external pressures and the outbreak of a general rate war}

Despite failing to neutralize the external pressures, the NDLV did improve cohesion among the members as joint action to regulate aspects of the passenger business became more common. Yet two aspects of the agreement still caused a lot of friction. Firstly, because of the tonnage clause, the lines expanded their fleets, decreasing the capacity utilization of their ships ${ }^{73}$. The number of services, such as that provided by the NGL Roland Line, carrying freight and steerage passengers at lower rates increased, which encouraged cheating. HAPAG converted sections of cattle steamers to carry the minimum amount of migrants. To make the tonnage count for the recalculation

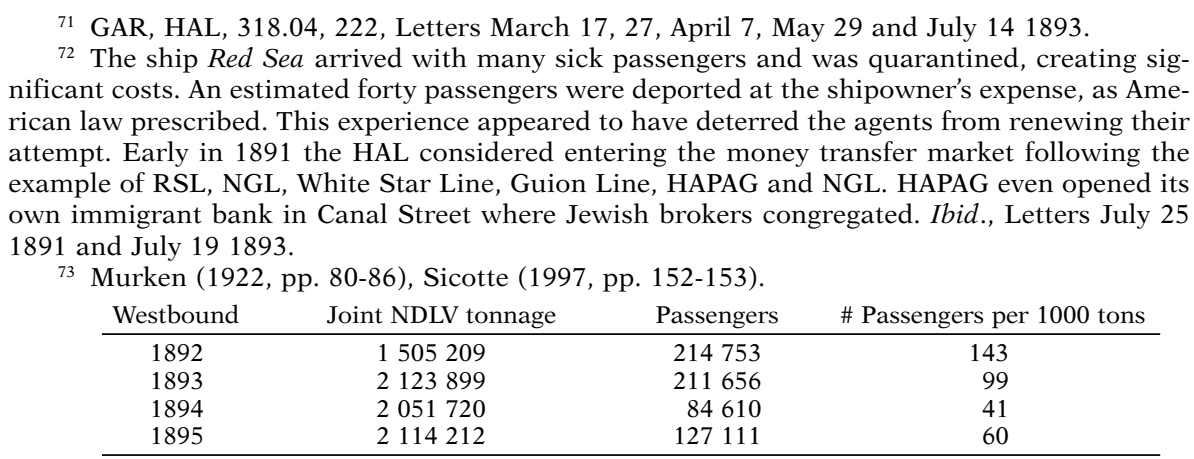


of their market share, companies needed to book fifty passengers westbound and fifteen eastbound. When it was feared that the quota was not going to be met, passengers could obtain «last minute deals». HAL secretly booked passengers at prices as low as $\$ 5$ net, while HAPAG even transported some free of charge. Instead of reducing overcapacity, the conference encouraged it with this clause and incited lines to cut rates. In 1895 the lines lowered the increase in market share attributed to a rise in tonnage before eliminating the tonnage clause in 1899 . The fact that the lines only signed a one-year instead of four-year contract, due to the non inclusion of all the British lines, constituted a second pressure point. This caused long annual discussions about market shares. During the initial years of the pool, members did not fully trust the system of fixed shares and it was felt that falling short could too often result in a reduction of the quota. Therefore lines paid extra commissions to make sure that quotas were filled, if not surpassed. This practice was reinforced because the rate agreements with British lines did not decrease the keen rivalry and violations persisted ${ }^{74}$.

Anticipating a pool agreement including the British lines which the directors negotiated in Europe, the head-agents of the Continental lines introduced «city rules» in New York, limiting ticket sales to joint company offices. Agents tried to stay in business by attempting to direct all their clients to the British lines. Van den Toorn was confident that the short term loss would largely be compensated by the long term gain of putting an end to the abuses and allowing the overland agencies to increase their sales ${ }^{75}$. Continental lines offered to withdraw completely from the British eastbound steerage market and to give up 12 per cent of the continental traffic. British lines, for their part, would not quote prices below the lowest price of pool members and cede a share of the Scandinavian market. The lines then seemed to settle for a counterproposal consisting of the Continental lines' withdrawal from British and Scandinavian markets while yielding only 6 per cent of continental traffic. Yet again, lack of unity among the British lines prevented the signing of the contract ${ }^{76}$. As negotiations proved unsuccessful, the Continental lines decided to start a rate war to force the British to a consensus. The fact that the market had collapsed because of the American financial crisis spurred the decisions. To limit the losses caused by rate wars, lines usually waited for recessions to force the weakest companies to make concessions.

All the agents in New York were reinstated and paid extra commissions ranging from $\$ 2$ to $\$ 5$. The Continental lines opened a regular service to

74 HAL paid $\$ 3,848$ extra commission the first nine months of 1892 . From March till July 1893 the amount reached $\$ 9,179$ and $\$ 12,739$ for the following six months. GAR, HAL, 318.04, 222, Letters March 20 and July 141893.

75 Ibid., 563, January 4, minutes 669-672; March 30 and April 4 1894, minutes 717-739 and ibid., 223, Letters April 1894.

76 Ibid., 223-226, Letters March 10 1893; January 18 and April 201894. 
Queenstown alternating sailings on the eastbound route, quoting net rates of $\$ 10$ and increased sailings to and from Southampton. The British lines used the orders of migrant brokers in Continental ports to undercut Continental fares, quoting $\$ 15$ from Rotterdam to New York ${ }^{77}$. The war also spread to the Mediterranean and Scandinavian markets ${ }^{78}$. Improved collaboration between the Continental lines as a result of the pool strengthened their position against the British lines whose collaboration was still based on less complex rate agreements, which weakened their unity. The American Line joined forces with the NDLV lines allowing these to attack the British on their internal westbound market ${ }^{79}$. For Continental traffic the NDLV initially responded to the price cuts of the British lines with extra commissions instead of lowering rates. This had the advantage of binding agents to the lines and prevented agents and brokers from speculating by writing out large numbers of prepaid blanks to be used when prices increased. Yet, it was impossible to prevent Continental passengers from taking advantage of the low British rates quoted by the NDLV lines and returning indirectly to Europe. Moreover, the British lines increased their share of the westbound continentals and a drastic cut of $\$ 8$ on prepaid and eastbound Continental rates followed ${ }^{80}$.

The slump in the market combined with the rate war put a lot of strain on both the pool and on the British lines with the Guion and National Line being forced out of the passenger business. In 1895 negotiations resumed and the lines agreed to stop the war and jointly raise fares. If both parties came to an agreement, agents and brokers would no longer be able to play out the rivalry to their advantage. Fearing exclusion from the market, the principal American agents formed the New York City Agent Association, headed by A. Falck, to discuss a suitable arrangement for agents and shipping lines. Agents agreed to abide by all conference rules and to stop drawing orders on European houses in exchange for a guarantee of a minimum amount of business and protection from the lines against the abuses of nonconference agents. The Hamburg brokers also signed a new agreement with the Continental and British lines to put an end to the abuses originating from the German port ${ }^{81}$. The long-awaited pool agreement finally materialized, limiting the British lines' share to 6 per cent of Continental traffic,

\footnotetext{
77 Ibid., Letter April 241894.

78 In the meantime some Continental and British lines had opened direct services from Italy to catch a share of the booming market. The NGL and HAPAG attacked the Scandinavian market, the latter reopening a direct service.

${ }^{79}$ Murken does not explain why the American Line was exempted from the restrictions imposed by the Board of Trade impeding foreign lines from transporting westbound steerage passengers from British ports. The agreement between the American Line and NDLV was reached at a conference in Cologne. GAR, HAL, 318.04, 223, Letter April 271894.

${ }^{80}$ GAR, HAL, 318.04, 563, July 26, 1894, minutes 775-777. Ibid., 223, Letters May 11 and September 51894.

${ }_{81}^{8}$ Ibid., June 19, minute 843, August 13, minutes 861-87 and September 4, minute 875.
} 
while Continental lines withdrew from the British and Scandinavian markets. It made it possible to impose conference rules on agents and brokers, which had important repercussions on transatlantic steerage fares. As the figure below illustrates, the pool agreement allowed Continental lines to increase prepaid prices significantly in 1892. Yet discord among the British lines delayed further increases and forced the companies to pay out high commissions, which cut into their profits. Prices plummeted during the war only to recuperate when negotiations resumed. When the extended pool agreement was signed, prices reached unprecedented levels. Compared to 1885 , HAL prepaid prices had doubled, rising from $\$ 17$ to $\$ 34$. The agreement would set new standards for fixing ocean fares for the following two decades ${ }^{82}$.

FIGURE

NEW YORK PREPAID FARES OF CONTINENTAL LINES 1890-1896

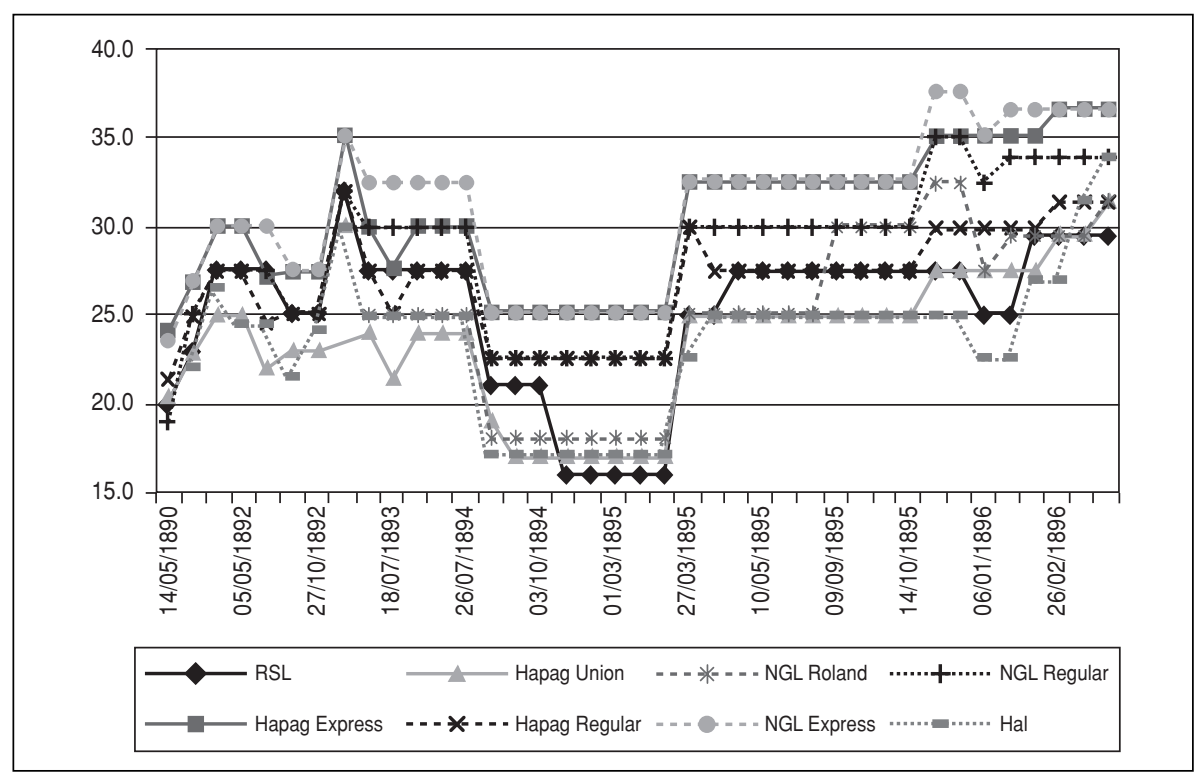

Passenger conferences, prepaid fares, profit distribution and migration costs: a complex story

The widespread networks of migrant agents on both sides of the Atlantic clearly undermined shipowners' ability to fix prices for transatlantic trans-

${ }^{82}$ Ibid., 223, Letter September 151985. 
port. Agents favored an unstable market because the keener the competition between the lines, the higher their commissions and the more facilities they obtained to increase their sales. The lack of a common interest between migrant agents and shipowners forced the latter to rely on conference rules to police the former. Shipping conferences which regulated passenger transport were as much a means of horizontal integration regulating competition between shipping companies as they were a means of vertical integration to gain control over the agent network. The analysis of the New York Continental Conference illustrates that it took the members a decade to find a workable equilibrium. A lasting agreement could only be reached once members had neutralized the competition of non conference Continental lines in their home ports. Yet, the distrust between members prevented them from making longstanding arrangements. The constant renegotiations on ocean rate differentials and the fact that fixed rates pushed the competition increasingly towards new and improved services, railroad rates and the tying of migrant brokers and agents to a line, impeded the conference from relieving the internal pressures between lines. Such internal pressures were intensified by the external pressures.

The success of the Continental Conference depended on the imposition of similar arrangements on the other sub-markets into which the North Atlantic passenger market was subdivided; the British-Scandinavian and Mediterranean. The conference agreements between the British lines concluded in the late1860's, the government protection of the home market from foreign competition, and the strong foothold in the Continental market via Hamburg allowed British companies to hold a dominant position on the North Atlantic passenger market. Continental lines therefore depended on the collaboration of the British lines to fix continental fares, commissions and impose rules on the migrant agent network to regulate sales. The lack of harmony between lines allowed migrant brokers to play off the rivalry to their advantage, increasing their control over the market. European migrant brokers opened branch offices in the US to exploit the price difference between European cash and American prepaid tickets, undercutting the shipping lines on the American market by issuing their own orders. Instead of making the market more transparent, all kinds of abuses concealing price cuts expanded during the first seven years of the Continental Conference. Cheating on conference agreements was too hard to detect and no effective means were put into place to deter lines and agents from doing so.

By dividing the market into shares with the formation of the NDLV, the Continental lines neutralized the internal incentives to cheat on the agreements and greatly improved the harmony among the members. The increased collaboration helped to increase the pressures on the British lines to reach a compromise. The lack of similar agreements between the members of the other sub-markets would subsequently allow the Continental lines to 
take the lead in the North-Atlantic steerage market. When these British lines joined the pool agreement, the Continental lines finally managed to impose themselves on the migrant agents, raise the gross rates and limit the price cuts from which the purchasers of transatlantic ocean passage had benefited especially. This significantly increased profits on steerage passenger sales of steamship lines, while augmenting the cost for migrants to cross the Atlantic. Before the agreement, excluding the lows of $\$ 10$ during rate wars, HAL's net prices varied between $\$ 15$ and $\$ 20$. In 1896 the rate reached $\$ 32$ which would set the standard for the next decades.

\section{BIBLIOGRAPHY}

\section{Sources}

Hamburg Staatsarchiv (HSA)

HSA, Consulaat Liverpool: Auswanderungsangelegenheiten 1851-68 nr 8.

The Rotterdam Community Archives: The Holland-America Line Archive (GAR-HAL)

318.02 Directie $V$

Nr. 112-118 Corresspondentie, private brieven van Van der Toorn, hoofdagentschap New York 1883-1914

318.04 Passage

GAR, HAL, 318.04, 221-226, Diverse brieven NASM New York, 1887-1897.

GAR, HAL, 318.04, 243, N.D.L.V. minutes.

GAR, HAL, 318.04, 563, Continental Conference minutes, 1885-1895.

GAR, HAL, 318.04, 580, N.D.L.V. minutes.

GAR, HAL, 318.04, 767, Diversen van den Toorn en Willmink.

\section{References}

ALdCROFT, D. (1974): Studies in British transport history, 1870-1970. London.

BASTIN, R. (1971): "Cunard and the Liverpool emigrant traffic 1860-1900». Unpublished Master thesis: University of Liverpool.

BoycE, G. (1995): Information, mediation and institutional development: The rise of large scale enterprise in British Shipping 1870-1919. Manchester.

BrattNe, B. (1976): «The Importance of the Transport Sector for Mass Migration», in H. Norman and H. Runblom (Eds.) From Sweden to America a history of the migration. Minneapolis, pp. 176-200.

Broeze, F. (1991): «Albert Ballin, The Hamburg-Bremen rivalry and the dynamics of the Conference system». The International Journal of Maritime History, 3 (1), pp 1-32.

DAY, J. (2002): "Credit, Capital and Community: Informal Banking in immigrant communities in the United States 1880-1924». Financial History Review, 9 (1), pp. 65-78. 
DEAKIN, B., and SEWARD, T. (1973): Shipping Conferences: a study of their origins, development and Economic practices. Cambridge.

Deltas, G.; Sefres, K., and Sicotte, R. (1999): «American Shipping Cartels in Pre World War I Era». Research in Economic History, 19 (1), pp. 1-38.

ENGELSING, R. (1961): Bremen als Auswandererhafen 1683-1880. Bremen.

EvANS, N. (2007): "The role of foreign-born agents in the development of mass migration through Britain, 1820-1923», in T. Feys, L. Fisher, S Hoste and S. Vanfraechem (Eds.) Maritime Transport and Migration: The Connections between Maritime and Migration Networks. St Johns, Newfoundland, pp. 49-62.

FEys, T. (2007): «Where all Passenger Liners meet:New York as a Nodal Point for the Transatlantic Migrant Trade». The International Journal of Maritime History, 19 (2), pp. 245-272.

FLAYHART, W. (1998): "The expansions of American interests in Transatlantic Commerce and trade 1865-1893», in D. Starkey and G. Harlafits (Eds.) Global Markets: The internationalization of the sea transport industries since 1850. St Johns, Newfoundland, pp. 127-147.

- (2000): The American Line 1872-1902. New York.

GELBERG, B. (1973): Auswanderung nach Übersee:Soziale Probleme der Auswanderungbeförderung in Hamburg und Bremen von der Mitte der 19. Jahrhunderts bis zum Ersten Weltkrieg. Hamburg.

Genesove, D., and Mullin, P. (2001): «Rules, Communication and Collusion: Narrative evidence from the Sugar Institute Case». The American Economic Review 91 (3), pp. 379-398.

GREENHILL, R. (1998): «Competition or cooperation the Global Shipping Industry: The origins and impact of the Conference system for British Shipowners before 1914», in D. Starkey and G. Harlafits (eds.), Global Markets: The internationalization of the sea transport industries since 1850. St John, Newfoundland, pp. 53-79.

HARLEY, K. (1988): «Ocean freight rates and productivity: 1740-1913: The primacy of mechanical invention reaffirmed», Journal of Economic History, 48 (4), pp. 851-876.

- (1990): «North Atlantic Shipping in the Late Nineteenth Century: Freight rates and the interrelationship of cargoes», in L. Fischer and H. Nordvik (eds.), Shipping and Trade 1750-1950. Leuven.

HuldermanN, B. (1922): Albert Ballin. Berlin.

HvidT, K. (1978): «Emigration Agents: The development of a business and its methods». Scandinavian Journal of History, 3 (2), pp. 178-202.

HydE, F. (1975): Cunard and the North Atlantic 1840-1973: A history of shipping and financial management. New Jersey.

KeELING, D. (1999a): «The Transport Revolution in the Transatlantic Migration 18501914». Research in Economic History, 19 (1), pp. 39-74.

- (1999b): «Transatlantic Shipping cartels and migration between Europe and America 1880-1914». Essays in Economic and Business History, 17 (2), pp. 195-213.

- (2007): "Costs, Risks, and Migration Networks between Europe and the United States, 1900-1914», in T. Feys, L. Fisher, S Hoste and S. Vanfraechem (eds.), Maritime Transport and Migration: The Connections between Maritime and Migration Networks. St Johns, Newfoundland, pp. $113-173$.

Murken, E. (1922): Die grossen transatlantischen Linienreederei-Verbande, Pools und Interessengemeinschaften bis zum Ausbruch des Weltkrieges: Ihre Entstehung, Organitsation und Wirksamkeit. Jena.

NoRTH, D. (1958): «Ocean freight rates and economical development: 1740-1913». Journal of Economic History, 48 (4), pp. 538-555. 
Osborne, D. (1976): "Cartel Problems». The American Historic Review, 66 (5), pp. 835-844.

OtTMUller-Wetzel, B. (1986): «Auswanderung über Hamburg: Die HAPAG und die Auswanderung nach Nordamerika 1870-1914». Unpublished master thesis, Freien Universitat Berlin.

PIRRong, S. (1992): "An application of Core theory to the Analysis of Ocean shipping markets». Journal of Law and Economics, 35 (1), pp. 89-131.

SAFFORD, J. (1985): "The decline of the American merchant marine 1850-1914: A historiographical appraisal», in L. Fischer and G. Panting (Eds.) Change and adaptation in maritime History: The North Atlantic fleets in the 19th century. St Johns, Newfoundland.

SicotTe, R. (1997): "Competition and Cartels in Liner Shipping Industry. A Historical Perspective», in Ulf Olsson (Ed.) Business and European Integration since 1800. Goteborg.

SJostrom, W. (2004): "The Stability of Ocean shipping Cartels», in P. Grossman (ed.) How Cartels endure and how they fail. Cheltenham.

SLOAN, E. (1998): "First and very secret international shipping cartel 1850-1856» in D. Starkey and G. Harlafits (eds.), Global Markets: The internationalization of the sea transport industries since 1850. St John, Newfoundland, pp. 31-52

- (1992): "Collins versus Cunard: The Realities of a North Atlantic Steamship rivalry 1850-58». The International Journal of Maritime History, 4 (1), pp. 83-100.

STIGLER, G. (1964): "A Theory of Oligopoly». Journal of Political Economy, 72 (1), 1964, pp. 44-61.

VAN DER VALK, L. (1976): "Landverhuizers via Rotterdam in de negentiende eeuw», in Economisch en Sociaal-Historisch jaarboek. Amsterdam.

VAnNoise-Pochulu, M. De (1993): "La politique de la Compagnie Générale Transatlantique et l'émigration vers les Etats-Unis à partir du Havre (1875-1914)». Unpublished Master thesis, Paris XII University.

VILLE, S. (1990): Transport and the devolopment of the European Economy 1750-1918. London.

WADHWANI, R. (2002): "Banking from the bottom up: the case of migrant savers at the Philadelphia Saving Fund Society at the late 19th Century». Financial History Review, 9 (1), pp. 41-63.

Williamson, J.; Hatton, T., and O’Rourke, K. (1994): «Mass migration, commodity market integration and real wage convergence: the late nineteenth century Atlantic economy», in J. Wiliamson and T. Hattan (eds.), International labour market integration and the impact of migration on the national labour markets since 1870. Milan.

Williamson, J., and Hatton T. (1998): The Age of Mass Migration: Causes and Economic Impact. Oxford.

WurstenBECKER, K. (2003): "Hamburg and the transit of east Europeans», in A. Fahrmeir, O. Faron and P. Weil (Eds.), Migration Control in the North Atlantic World. New York. 


\section{APPENDIX 1}

The New York Conferences, members and ports from which they operated 1885-1895

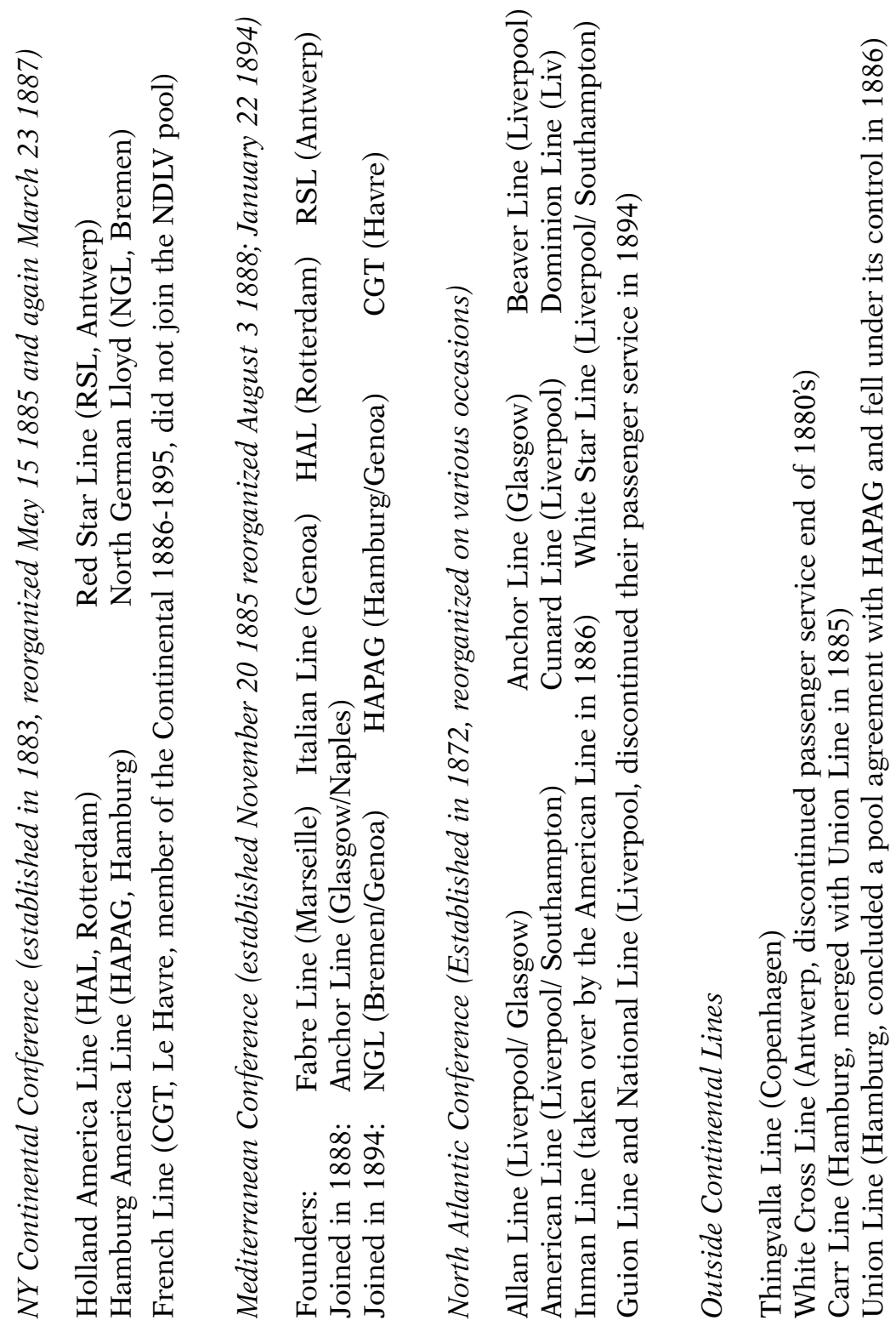


TORSTEN FEYS

\section{APPENDIX 2}

Prepaid rates in dollars of the Continental lines» New York services

\begin{tabular}{|c|c|c|c|c|c|c|c|c|}
\hline & HAL & RSL & HAPAG & $\begin{array}{l}\text { HAPAG } \\
\text { Express }\end{array}$ & $\begin{array}{c}\text { HAPAG } \\
\text { Union }\end{array}$ & NGL & $\begin{array}{c}\text { NGL } \\
\text { Express }\end{array}$ & $\begin{array}{l}\text { NGL } \\
\text { Roland }\end{array}$ \\
\hline $30 / 4 / 1885$ & 18 & 20 & 20 & & & 20 & 22 & \\
\hline $15 / 5 / 1885$ & 17 & 20 & 20 & & & 20 & 22 & \\
\hline 28/7/1885 & 19.5 & 22.5 & 22.5 & & & 22.5 & 24.5 & \\
\hline $10 / 11 / 1885$ & 22 & 25 & 25 & & & 25 & & \\
\hline $01 / 03 / 1886$ & 22 & 25 & 25 & & 23 & 25 & 27 & \\
\hline 02/08/1886 & 22 & 15 & 25 & & 23 & 25 & 27 & \\
\hline 03/08/1886 & 12 & 15 & 15 & & 13 & 15 & 17 & \\
\hline $16 / 04 / 1887$ & 21 & 23 & 24 & & 22 & discontinued & 25 & \\
\hline $01 / 12 / 1887$ & 20.5 & 22.5 & 23.5 & & 22 & discontinued & 26 & \\
\hline $01 / 02 / 1889$ & 20.5 & 22 & 23.5 & 26 & 22 & 23 & 26 & \\
\hline $15 / 10 / 1889$ & 21 & 22 & 23.5 & 26 & 22 & discontinued & 26 & \\
\hline $14 / 05 / 1890$ & 19 & 20 & 21.5 & 24 & 20.5 & discontinued & 24 & \\
\hline $07 / 03 / 1892$ & 22 & 23 & 25 & 27 & 23 & 25 & 27 & \\
\hline 09/04/1892 & 26.5 & 27.5 & 27.5 & 30 & 25 & 27.5 & 30 & \\
\hline 05/05/1892 & 24.5 & 27.5 & 27.5 & 30 & 25 & 27.5 & 30 & \\
\hline $22 / 06 / 1892$ & 24.5 & 27.5 & 24.5 & 27 & 22 & 27.5 & 30 & \\
\hline 01/07/1892 & 21.5 & 25 & 24.5 & 27 & 22 & 27.5 & 30 & \\
\hline 04/09/1892 & 21.5 & 25 & 24.5 & 27 & 22 & 27.5 & 30 & \\
\hline 27/10/1892 & 24 & 25 & 24.5 & 27 & 22 & 27.5 & 30 & \\
\hline $01 / 03 / 1893$ & 30 & 32 & 32 & 35 & 30 & 32 & 35 & \\
\hline $04 / 04 / 1893$ & 25 & 27.5 & 27.5 & 30 & 24 & 30 & 32.5 & 25 \\
\hline 13/07/1893 & 25 & 27.5 & 25 & 27.5 & 21.5 & 30 & 32.5 & 25 \\
\hline 03/09/1893 & 25 & 27.5 & 27.5 & 30 & 24 & 30 & 32.5 & 25 \\
\hline 02/08/1894 & 17 & 21 & 27.5 & 30 & 24 & 30 & 32.5 & 25 \\
\hline 03/08/1894 & 17 & 21 & 27.5 & 30 & 24 & 22.5 & 25 & 18 \\
\hline 04/08/1894 & 17 & 21 & 22.5 & 25 & 19 & 22.5 & 25 & 18 \\
\hline 21/08/1894 & 17 & 21 & 22.5 & 25 & 17 & 22.5 & 25 & 18 \\
\hline $03 / 11 / 1894$ & 17 & 16 & 22.5 & 25 & 17 & 22.5 & 25 & 18 \\
\hline 27/03/1895 & 22.5 & 25 & 30 & 32.5 & 25 & 30 & 32.5 & 25 \\
\hline 05/04/1895 & 25 & 25 & 30 & 32.5 & 25 & 30 & 32.5 & 25 \\
\hline $11 / 04 / 1895$ & 25 & 25 & 27.5 & 32.5 & 25 & 30 & 32.5 & 25 \\
\hline $13 / 04 / 1895$ & 25 & 27.5 & 27.5 & 32.5 & 25 & 30 & 32.5 & 25 \\
\hline 09/09/1895 & 25 & 27.5 & 27.5 & 32.5 & 25 & 30 & 32.5 & 30 \\
\hline $14 / 11 / 1895$ & 25 & 27.5 & 30 & 35 & 27.5 & 35 & 37.5 & 32.5 \\
\hline 01/01/1896 & 25 & 27.5 & 30 & 35 & 27.5 & 32.5 & 35 & 27.5 \\
\hline $06 / 01 / 1896$ & 22.5 & 27.5 & 30 & 35 & 27.5 & 32.5 & 35 & 27.5 \\
\hline 08/01/1896 & 22.5 & 25 & 30 & 35 & 27.5 & 32.5 & 35 & 27.5 \\
\hline $12 / 02 / 1896$ & 22.5 & 25 & 30 & 35 & 27.5 & 34 & 36.5 & 29.5 \\
\hline $18 / 02 / 1896$ & 27 & 29.5 & 30 & 35 & 27.5 & 34 & 36.5 & 29.5 \\
\hline $26 / 02 / 1896$ & 27 & 29.5 & 31.5 & 36.5 & 29.5 & 34 & 36.5 & 29.5 \\
\hline 13/03/1896 & 31.5 & 29.5 & 31.5 & 36.5 & 29.5 & 34 & 36.5 & 29.5 \\
\hline 19/031896 & 34 & 29.5 & 31.5 & 36.5 & 29.5 & 34 & 36.5 & 29.5 \\
\hline 21-3-1896 & 34 & 29.5 & 31.5 & 36.5 & 31.5 & 34 & 36.5 & 31.5 \\
\hline
\end{tabular}

